\title{
Assessment of Quality of Ground Water in Kasaba Bawada Kolhapur
}

\author{
${ }^{1}$ Patil Ajit A ${ }^{2}$ S. M. Bhosale \\ ${ }^{1}$ Research Student ${ }^{2}$ Assistant Professor \\ Department of Technology, Shivaji University, Kolhapur, \\ Maharashtra, India
}

\begin{abstract}
Water is one of the most crucial components for all forms of life. Quality of water is equally important to the quantity available. Only $2 \%$ as fresh water in the form of surface and subsurface water bodies and it usable for the human consumption. So when we consume water its quality measurements are necessary and management should be done in systematic path. Water quality is directly related to the physical, chemical, biological and radiological property of water, these properties of water are affected due to the pollution of water due to various human activities. Depend on the activities; disposal of pollutant in the water bodies are done that changes the standard quantity of parameters in water. This research paper deals with the studies carried out to assess the Ground Water Quality at Kasaba-Bawda village in Karveer Tahasil of Kolhapur District of Maharashtra. Water samples from ten discrete locations comprised of Open Wells, Tube-Wells and a Fixed Masonry Reservoirs were chosen based on their distance from polluting source identified were selected for the Ground Water sampling to study the impacts of solid waste dumping on the Ground Water Quality of publically available drinking water sources at selective locations. The quality was assessed in terms of major parameters, like $\mathrm{pH}$, turbidity, hardness, chloride, alkalinity, etc. the water from the water sources located in the vicinity of solid waste dumping sites were slightly polluted making the water unfit for drinking.
\end{abstract}

Keywords: Groundwater, Water Pollution, Water quality, Surface water, solid waste, Tube well.

\section{INTRODUCTION}

The modern civilization accompanied by the rapid growth of population and industrialization has created the situation of huge amount of solid waste generation in cities and towns. All over the world today the cities are vexed with the problem of disposal and management of generated solid waste, In Kolhapur city the solid wastes are collected, Transported and disposed at the dumping site by the Kolhapur Municipal Corporation (kMC) authority. The present dumping site at Kasaba bawada dumping area Kolhapur. The leachate is produced from the decomposition and squeezing of wastes and by water that has entered the dumping site from external sources. It carries a number of dissolved and suspected impurities as it moves down through the wastes. The leachate generated from the MSW-Municipal Solid Waste dumping site can seep slowly through the layers of soil beneath and percolates down to the ground water rendering it unsuitable for the designated use. The leachate pollution can cover wide areas depending on the aquifer characteristics. The contamination of ground water due to MSW material has been a serious concern to us. The present study aims at evaluation of the ground water quality at different distances of MSW dumping site at Kasaba bawada dumping area as well as to ascertain the contamination of ground water due to MSW disposal. In order to know the groundwater quality of the village, we have identified $\mathbf{1 0}$ sampling stations from dug wells and bore wells covering entire kasaba bawada and adjacent villages of study area. This contaminated water, in kasaba bawada going to high rate of health hazards. Bad quality of water produces diseases in this area. Polluted Water from suger industry and dumping site, directly discharge to water body. Zoom project also waste is burn and incineration take place at sight itself. In rainy season this polluted water and air mix with groundwater and surface water and water quality gets polluted so, identification of source and analysis of quality water is very important in this region.

\section{MATERIALS AND METHODS}

For the present study of municipal solid waste, the Kasaba Bawada dumping site near Kolhapur was selected. Ground water sources at different distances from the fringe of the dumping site were selected for the study. Five well water samples and five bore well water samples were collected from different distances within of dumping sites. After measuring physical parameters like $\mathrm{pH}$, temperature, colour the samples collected from the sampling sites were brought the laboratory for chemical analysis. Chemical parameters like turbidity, DO, hardness, Nitrate, TS, TDS, TSS, Chloride, Alkalinity, sulphate, calcium are estimated. The analysis was performed by following standard methods for the examination of water and wastewater.

\section{METHODOLOGY}

In order to mitigate the problem, following approach is adopted:

To assess the water quality of Kasaba Bawada for parametric quantity as follows

A) Collection of water sample:

For the present investigation along the stretch of kasaba bawada dumping area ten water testing stations selected. five well water samples to be specific: D.y.patil well, krushi farm well, rajaram mill well, bedekar well, khole patil well .five bore well water samples to be specific: Maratha colony, biranje panand area, wadkar galli, line bazar, D.y.patil well.

B) To analysis the factors affecting to water resources 
C) The project was based on testing the quality of water .samples were collected from bore wells, wells, near kasaba bawada area. $1^{\text {st }}$ sample after the rainy season and $2^{\text {nd }}$

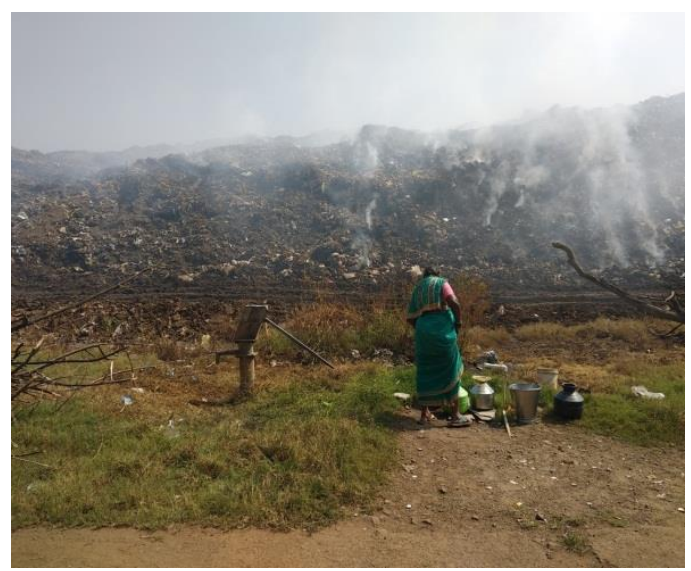

A) DUMPING SITE sample in winter season and third sample in summer season.

D) To collect water samples and analyze its physical, chemical, parameters.

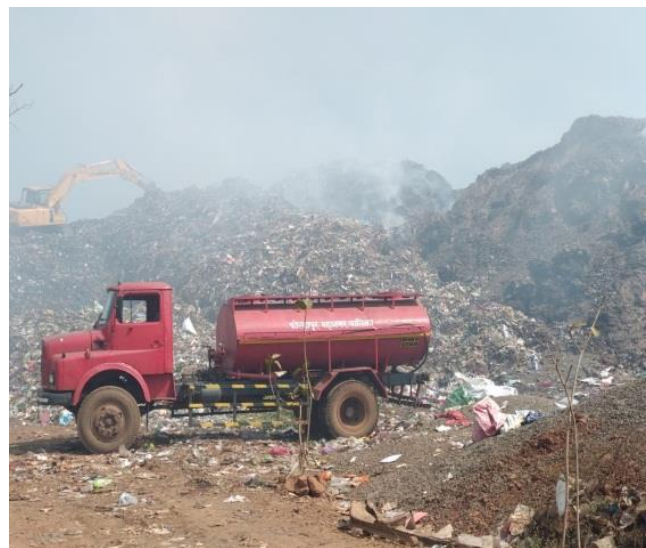

B) DUMPING SITE WATER SPRINK

RESULTS AND DISCUSSION

WINTER SEASON WELL WATER SAMPLE

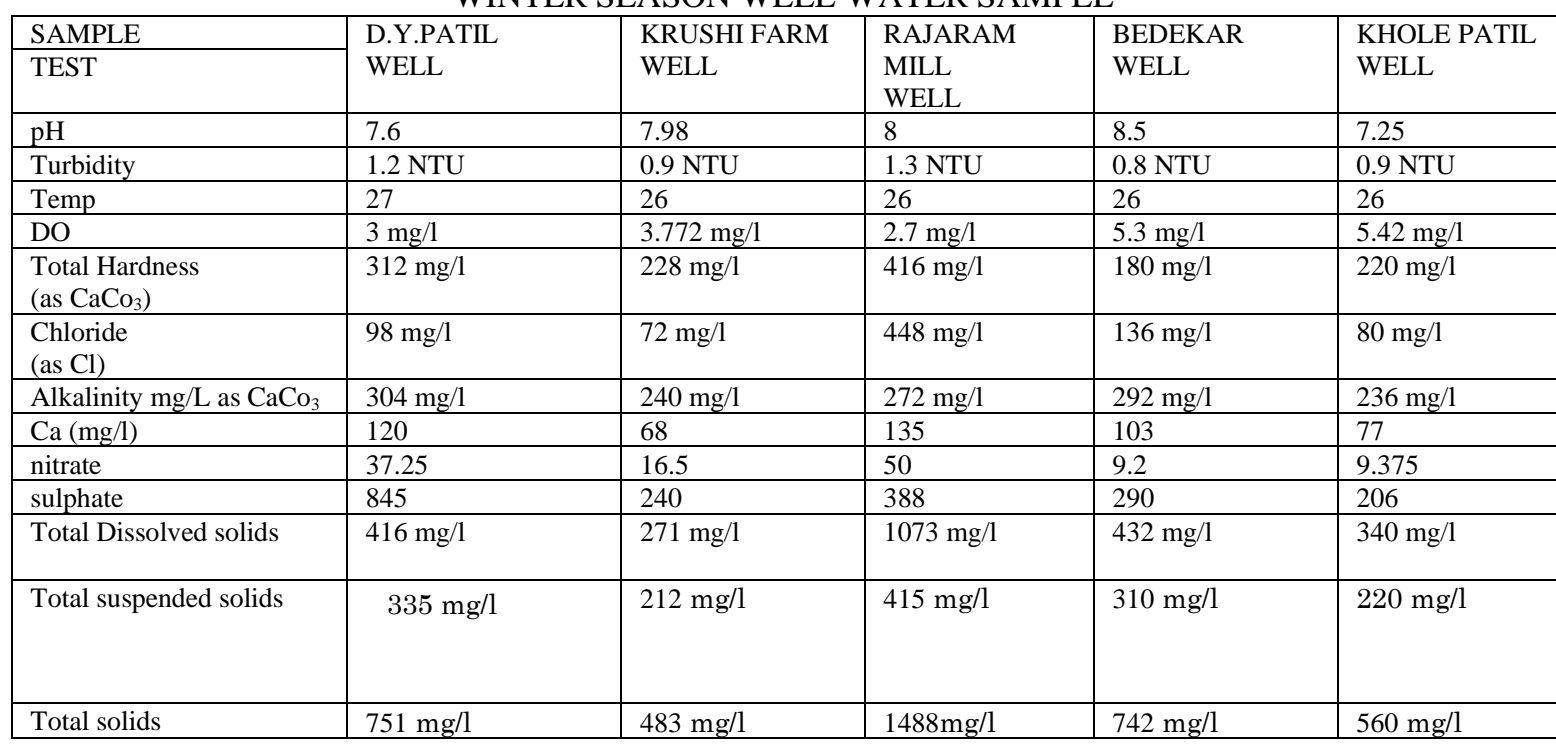

\begin{tabular}{|c|c|c|c|c|c|}
\hline SAMPLE & PADMA PATHAK & MARATHA & DATTA & BIRANJE & D.Y PATIL \\
\hline TEST & COLONY & COLONY & MADIR & PANAD ROAD & FARM \\
\hline $\mathrm{pH}$ & 7.96 & 7.68 & 7.99 & 7.12 & 7.49 \\
\hline Temp & 22 & 23 & 22 & 24 & 25 \\
\hline DO & $2.11 \mathrm{mg} / \mathrm{l}$ & $2.64 \mathrm{mg} / \mathrm{l}$ & $2.35 \mathrm{mg} / \mathrm{l}$ & $3 \mathrm{mg} / \mathrm{l}$ & $3.21 \mathrm{mg} / 1$ \\
\hline $\begin{array}{l}\text { Chloride } \\
\text { (as } \mathrm{Cl} \text { ) }\end{array}$ & $64 \mathrm{mg} / 1$ & $58 \mathrm{mg} / \mathrm{l}$ & $102 \mathrm{mg} / 1$ & $1278 \mathrm{mg} / \mathrm{l}$ & $138 \mathrm{mg} / \mathrm{l}$ \\
\hline Alkalinity $\mathrm{mg} / \mathrm{L}$ as $\mathrm{CaCo}_{3}$ & $192 \mathrm{mg} / \mathrm{l}$ & $292 \mathrm{mg} / \mathrm{l}$ & $288 \mathrm{mg} / \mathrm{l}$ & $436 \mathrm{mg} / \mathrm{l}$ & $308 \mathrm{mg} / \mathrm{l}$ \\
\hline $\mathrm{Ca}(\mathrm{mg} / \mathrm{l})$ & 110 & 56 & 88 & 70 & 160 \\
\hline nitrate & 2.586 & 3.2 & 3.373 & 14.9 & 26.85 \\
\hline sulphate & 12.08 & 18.83 & 34.12 & 588 & 584 \\
\hline
\end{tabular}


SUMMER SEASON WELL WATER SAMPLE

\begin{tabular}{|l|l|l|l|l|l|}
\hline SAMPLE & $\begin{array}{l}\text { D.Y.PATIL } \\
\text { WELL }\end{array}$ & $\begin{array}{l}\text { KRUSHI } \\
\text { FARM WELL }\end{array}$ & $\begin{array}{l}\text { RAJARAM } \\
\text { MILL } \\
\text { WELL }\end{array}$ & $\begin{array}{l}\text { BEDEKAR } \\
\text { WELL }\end{array}$ & $\begin{array}{l}\text { KHOLE } \\
\text { PATIL } \\
\text { WELL }\end{array}$ \\
\hline $\mathrm{pH}$ & 7.9 & 8.2 & 8.6 & 8.9 & 7.25 \\
\hline Turbidity & $1.3 \mathrm{NTU}$ & $0.7 \mathrm{NTU}$ & $1.1 \mathrm{NTU}$ & $0.7 \mathrm{NTU}$ & $0.8 \mathrm{NTU}$ \\
\hline Temp & 29 & 28 & 28 & 27 & 27 \\
\hline DO & $3.2 \mathrm{mg} / \mathrm{l}$ & $3.54 \mathrm{mg} / \mathrm{l}$ & $2.31 \mathrm{mg} / \mathrm{l}$ & $4.56 \mathrm{mg} / \mathrm{l}$ & $5.12 \mathrm{mg} / \mathrm{l}$ \\
\hline $\begin{array}{l}\text { Total Hardness } \\
\text { (as CaCo }\end{array}$
\end{tabular}

SUMMER SEASON BORE WELL WATER SAMPLE

\begin{tabular}{|c|c|c|c|c|c|}
\hline $\begin{array}{l}\text { SAMPLE } \\
\text { TEST }\end{array}$ & $\begin{array}{l}\text { PADMA } \\
\text { PATHAK } \\
\text { COLONY }\end{array}$ & $\begin{array}{l}\text { MARATHA } \\
\text { COLONY }\end{array}$ & $\begin{array}{l}\text { DATTA } \\
\text { MADIR }\end{array}$ & $\begin{array}{l}\text { BIRANJE } \\
\text { PANAD } \\
\text { ROAD }\end{array}$ & $\begin{array}{l}\text { D.Y PATIL } \\
\text { FARM }\end{array}$ \\
\hline $\mathrm{pH}$ & 7.8 & 7.98 & 8.12 & 7.35 & 7.22 \\
\hline Turbidity & $0.3 \mathrm{NTU}$ & $0.6 \mathrm{NTU}$ & $1.6 \mathrm{NTU}$ & $1.8 \mathrm{NTU}$ & $0.4 \mathrm{NTU}$ \\
\hline Temp & 26 & 26 & 26 & 27 & 28 \\
\hline DO & $2.1 \mathrm{mg} / \mathrm{l}$ & $3.32 \mathrm{mg} / \mathrm{l}$ & $2.12 \mathrm{mg} / \mathrm{l}$ & $3.45 \mathrm{mg} / \mathrm{l}$ & $3.12 \mathrm{mg} / \mathrm{l}$ \\
\hline $\begin{array}{l}\text { Total Hardness } \\
\left(\text { as } \mathrm{CaCo}_{3}\right)\end{array}$ & $153 \mathrm{mg} / \mathrm{l}$ & $286 \mathrm{mg} / 1$ & $196 \mathrm{mg} / \mathrm{l}$ & $437 \mathrm{mg} / \mathrm{l}$ & $412 \mathrm{mg} / \mathrm{l}$ \\
\hline $\begin{array}{l}\text { Chloride } \\
\text { (as } \mathrm{Cl} \text { ) }\end{array}$ & $98 \mathrm{mg} / \mathrm{l}$ & $65 \mathrm{mg} / \mathrm{l}$ & $88 \mathrm{mg} / \mathrm{l}$ & $1126 \mathrm{mg} / \mathrm{l}$ & $194 \mathrm{mg} / \mathrm{l}$ \\
\hline $\begin{array}{l}\text { Alkalinity } \mathrm{mg} / \mathrm{L} \text { as } \\
\mathrm{CaCo}_{3}\end{array}$ & $175 \mathrm{mg} / \mathrm{l}$ & $314 \mathrm{mg} / \mathrm{l}$ & $321 \mathrm{mg} / \mathrm{l}$ & $423 \mathrm{mg} / \mathrm{l}$ & $288 \mathrm{mg} / \mathrm{l}$ \\
\hline $\mathrm{Ca}(\mathrm{mg} / \mathrm{l})$ & 100 & 78 & 102 & 66 & 125 \\
\hline nitrate & 2.9 & 3.2 & 3.722 & 16.45 & 27.10 \\
\hline sulphate & 11.73 & 16.72 & 29.82 & 510 & 614 \\
\hline Total Dissolved solids & $208 \mathrm{mg} / \mathrm{l}$ & $344 \mathrm{mg} / \mathrm{l}$ & $323 \mathrm{mg} / \mathrm{l}$ & $1765 \mathrm{mg} / \mathrm{l}$ & $512 \mathrm{mg} / \mathrm{l}$ \\
\hline Total suspended solids & $202 \mathrm{mg} / 1$ & $276 \mathrm{mg} / 1$ & $304 \mathrm{mg} / 1$ & $1112 \mathrm{mg} / \mathrm{l}$ & $438 \mathrm{mg} / 1$ \\
\hline Total solids & $410 \mathrm{mg} / 1$ & $620 \mathrm{mg} / 1$ & $627 \mathrm{mg} / \mathrm{l}$ & $2877 \mathrm{mg} / \mathrm{l}$ & $950 \mathrm{mg} / \mathrm{l}$ \\
\hline
\end{tabular}


MONSOON SEASON WELL WATER SAMPLE

\begin{tabular}{|l|l|l|l|l|l|}
\hline SAMPLE & $\begin{array}{l}\text { D.Y.PATIL } \\
\text { WELL }\end{array}$ & $\begin{array}{l}\text { KRUSHI FARM } \\
\text { WELL }\end{array}$ & $\begin{array}{l}\text { RAJARAM } \\
\text { MILL } \\
\text { WELL }\end{array}$ & $\begin{array}{l}\text { BEDEKAR } \\
\text { WELL }\end{array}$ & $\begin{array}{l}\text { KHOLE } \\
\text { PATIL WELL }\end{array}$ \\
\hline TEST & 7.46 & 7.44 & 7.28 & 7.30 & 7.15 \\
\hline Turbidity & $0.3 \mathrm{NTU}$ & $0 \mathrm{NTU}$ & $0 \mathrm{NTU}$ & $12.5 \mathrm{NTU}$ & $0 \mathrm{NTU}$ \\
\hline Temp & 28 & 27 & 26 & 25 & 25 \\
\hline DO & $1.06 \mathrm{mg} / \mathrm{l}$ & $3.86 \mathrm{mg} / \mathrm{l}$ & $2.06 \mathrm{mg} / \mathrm{l}$ & $5.34 \mathrm{mg} / \mathrm{l}$ & $3 \mathrm{mg} / \mathrm{l}$ \\
\hline $\begin{array}{l}\text { Total Hardness } \\
\text { (as CaCo }\end{array}$
\end{tabular}

\begin{tabular}{|c|c|c|c|c|c|}
\hline $\begin{array}{l}\text { SAMPLE } \\
\text { TEST }\end{array}$ & $\begin{array}{l}\text { PADMA } \\
\text { PATHAK }\end{array}$ & $\begin{array}{l}\text { MARATHA } \\
\text { COLONY }\end{array}$ & DATTA & BIRANJE & D.Y PATIL \\
\hline TEST & $\begin{array}{l}\text { PATHAK } \\
\text { COLONY }\end{array}$ & COLONY & MADIR & PANAD ROAD & FARM \\
\hline $\mathrm{pH}$ & 6.8 & 7.01 & 7.67 & 6.81 & 7.35 \\
\hline Turbidity & $1.4 \mathrm{NTU}$ & $0 \mathrm{NTU}$ & $0.9 \mathrm{NTU}$ & $1.5 \mathrm{NTU}$ & $8.2 \mathrm{NTU}$ \\
\hline Temp & 23 & 23 & 24 & 25 & 26 \\
\hline DO & $4.6 \mathrm{mg} / \mathrm{l}$ & $4.8 \mathrm{mg} / \mathrm{l}$ & $3.2 \mathrm{mg} / \mathrm{l}$ & $2.1 \mathrm{mg} / \mathrm{l}$ & $1.6 \mathrm{mg} / \mathrm{l}$ \\
\hline $\begin{array}{l}\text { Total Hardness } \\
\left(\text { as } \mathrm{CaCo}_{3}\right)\end{array}$ & $232 \mathrm{mg} / \mathrm{l}$ & $240 \mathrm{mg} / \mathrm{l}$ & $200 \mathrm{mg} / \mathrm{l}$ & $1400 \mathrm{mg} / \mathrm{l}$ & $148 \mathrm{mg} / \mathrm{l}$ \\
\hline $\begin{array}{l}\text { Chloride } \\
\text { (as } \mathrm{Cl} \text { ) }\end{array}$ & $38 \mathrm{mg} / \mathrm{l}$ & $58 \mathrm{mg} / \mathrm{l}$ & $78 \mathrm{mg} / \mathrm{l}$ & $1088 \mathrm{mg} / \mathrm{l}$ & $52 \mathrm{mg} / \mathrm{l}$ \\
\hline $\begin{array}{l}\text { Alkalinity } \mathrm{mg} / \mathrm{L} \text { as } \\
\mathrm{CaCo}_{3}\end{array}$ & $248 \mathrm{mg} / \mathrm{l}$ & $336 \mathrm{mg} / 1$ & $248 \mathrm{mg} / \mathrm{l}$ & $500 \mathrm{mg} / \mathrm{l}$ & $116 \mathrm{mg} / \mathrm{l}$ \\
\hline $\mathrm{Ca}(\mathrm{mg} / \mathrm{l})$ & 121 & 66 & 52 & 64 & 140 \\
\hline nitrate & 2.386 & 3.6 & 4.284 & 15.75 & 27.75 \\
\hline sulphate & 19.7 & 26.8 & 40.32 & 650 & 550 \\
\hline Total Dissolved solids & $242 \mathrm{mg} / \mathrm{l}$ & $328 \mathrm{mg} / \mathrm{l}$ & $331 \mathrm{mg} / \mathrm{l}$ & $1733 \mathrm{mg} / \mathrm{l}$ & $267 \mathrm{mg} / \mathrm{l}$ \\
\hline Total suspended solids & $229 \mathrm{mg} / \mathrm{l}$ & $225 \mathrm{mg} / \mathrm{l}$ & $212 \mathrm{mg} / \mathrm{l}$ & $1027 \mathrm{mg} / \mathrm{l}$ & $197 \mathrm{mg} / \mathrm{l}$ \\
\hline Total solids & $471 \mathrm{mg} / \mathrm{l}$ & $553 \mathrm{mg} / \mathrm{l}$ & $543 \mathrm{mg} / \mathrm{l}$ & $2760 \quad \mathrm{mg} / \mathrm{l}$ & $464 \mathrm{mg} / \mathrm{l}$ \\
\hline
\end{tabular}

Fig 1 Comparison of $\mathrm{Ph}$. values of well water

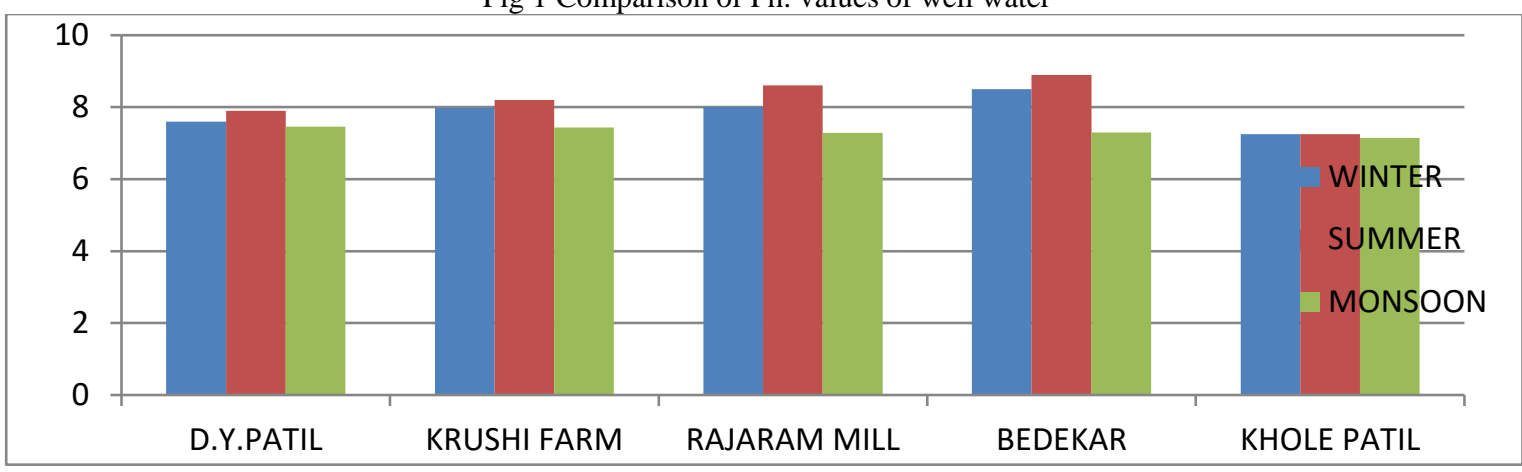


Fig 2 comparison of $\mathrm{Ph}$. of bore well water

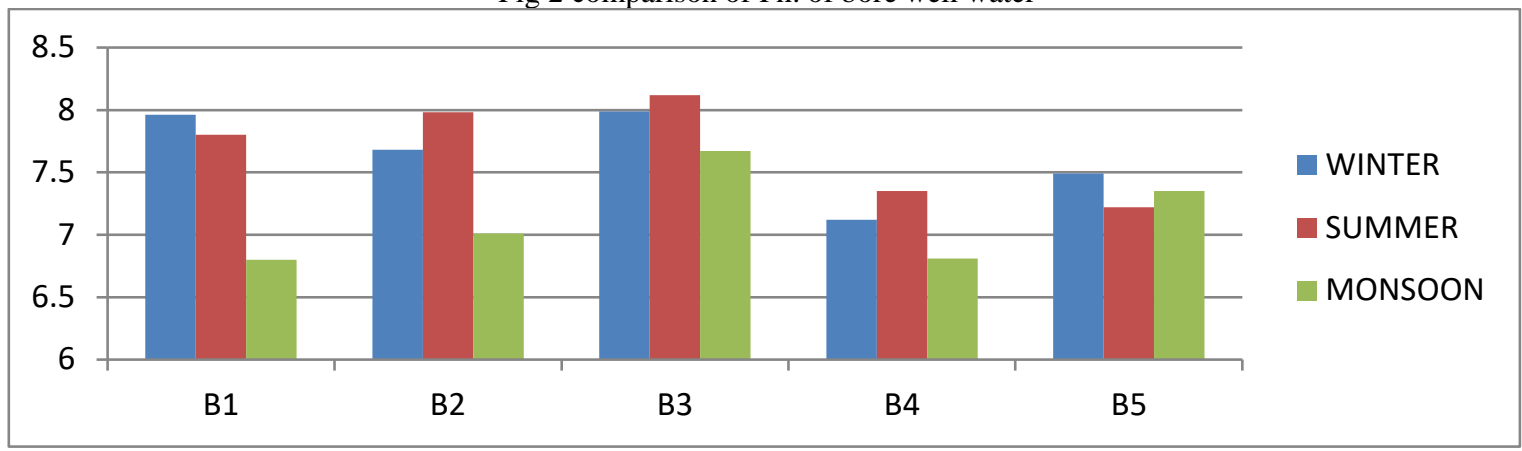

Fig 3 Comparison of turbidity of well water

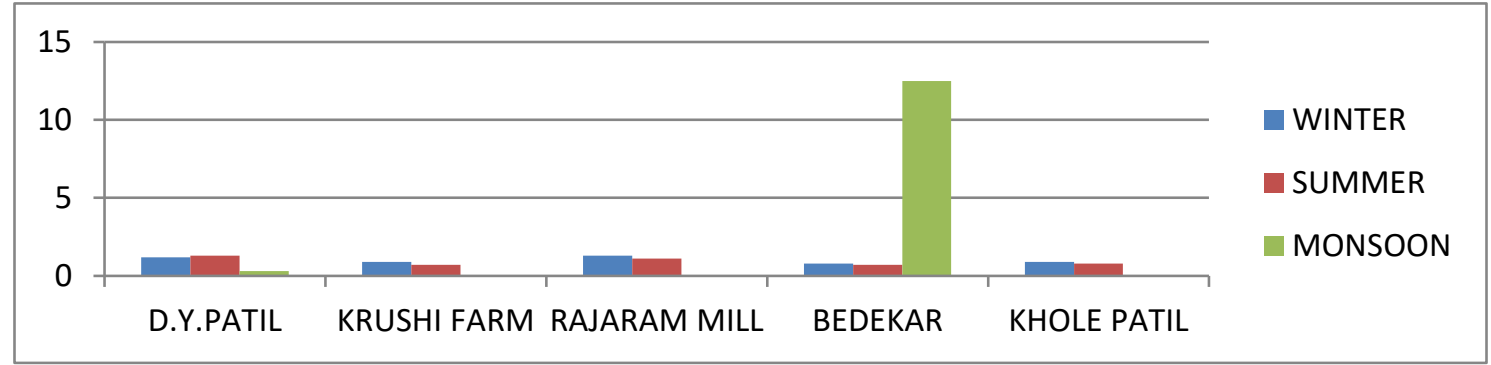

Fig 4 Comparison of turbidity of bore well water

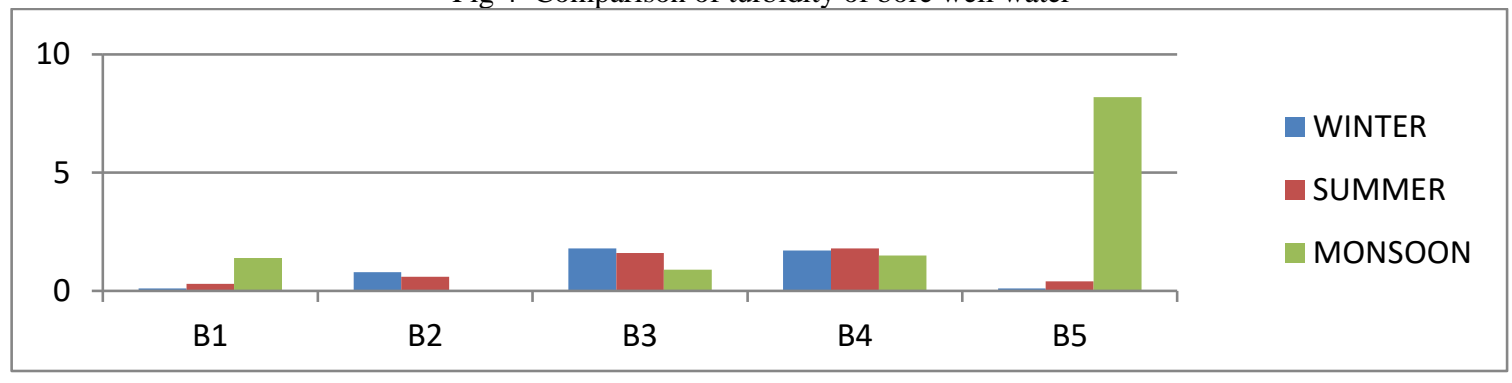

Fig 5 comparison of hardness of well water sample

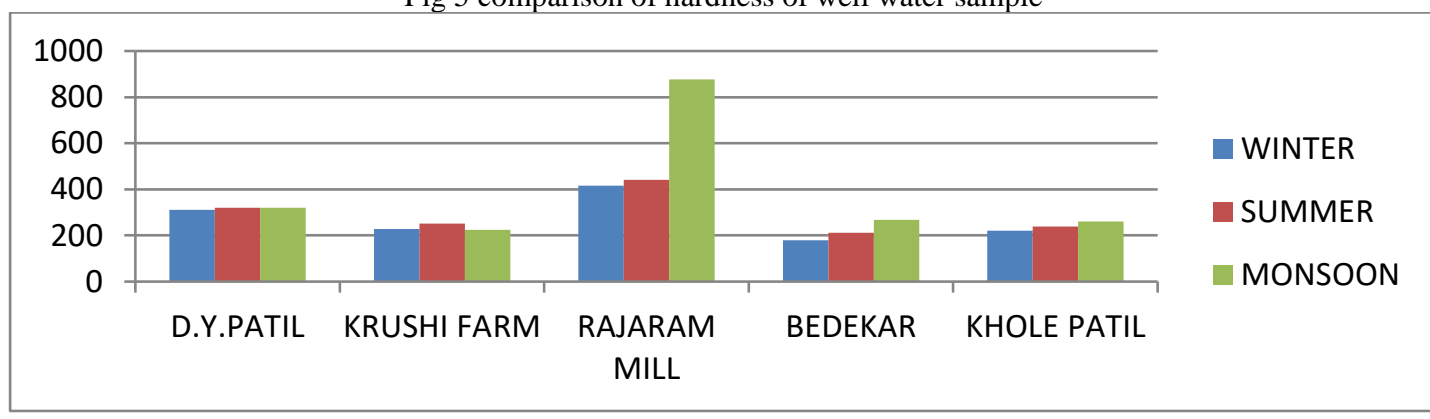

Fig 6 comparison of hardness of bore well water sample

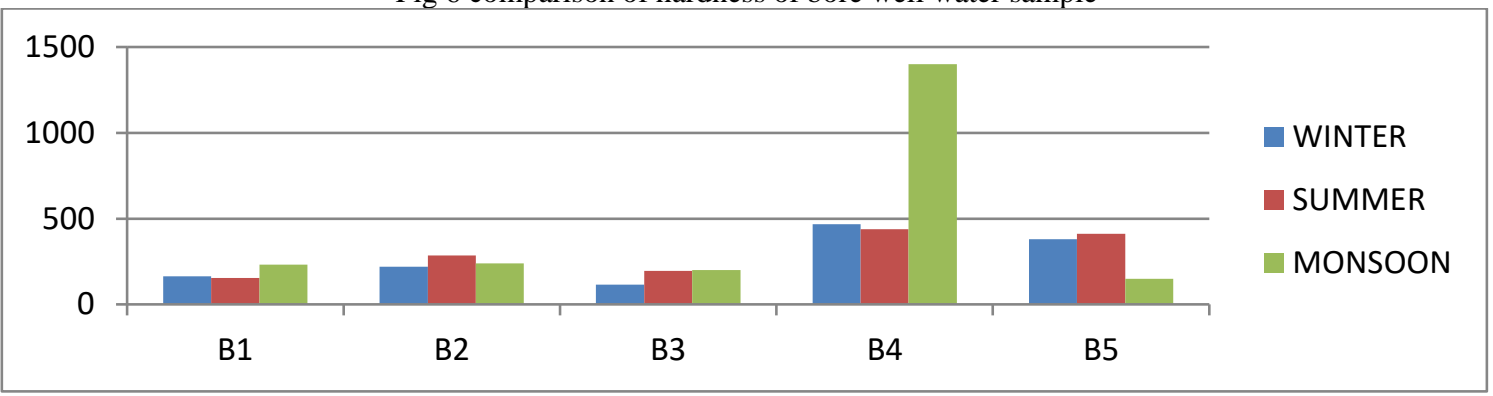


Fig 7 comparison of chloride of well water sample

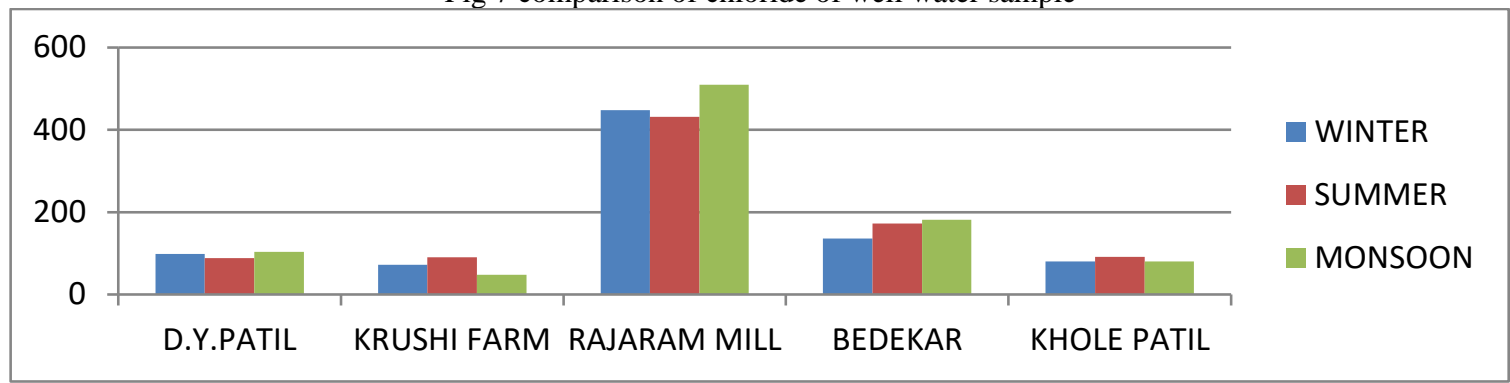

Fig 8 comparison of chloride of bore well water sample

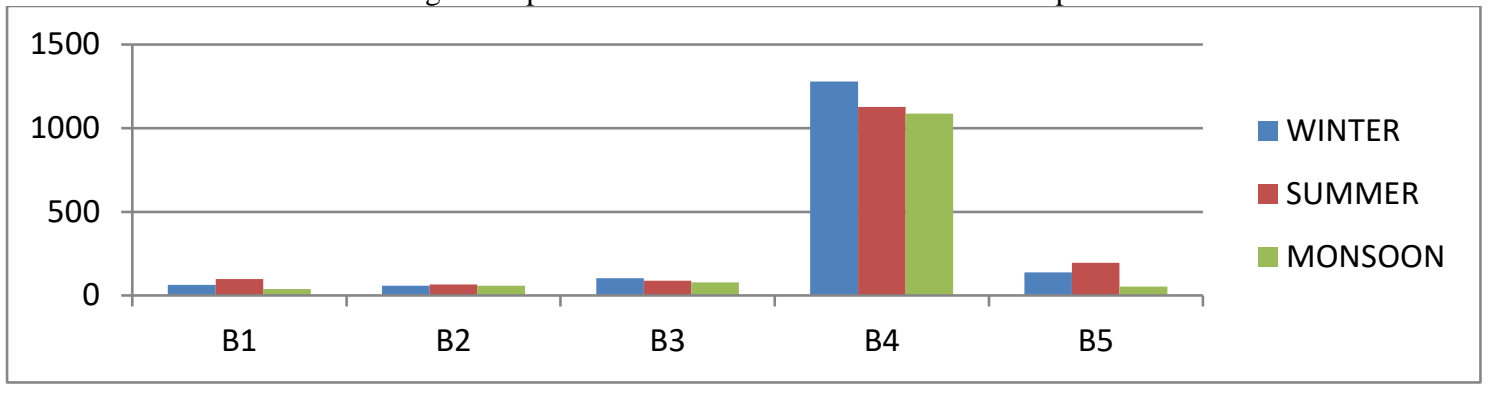

Fig 9 comparison of alkalinity of well water sample

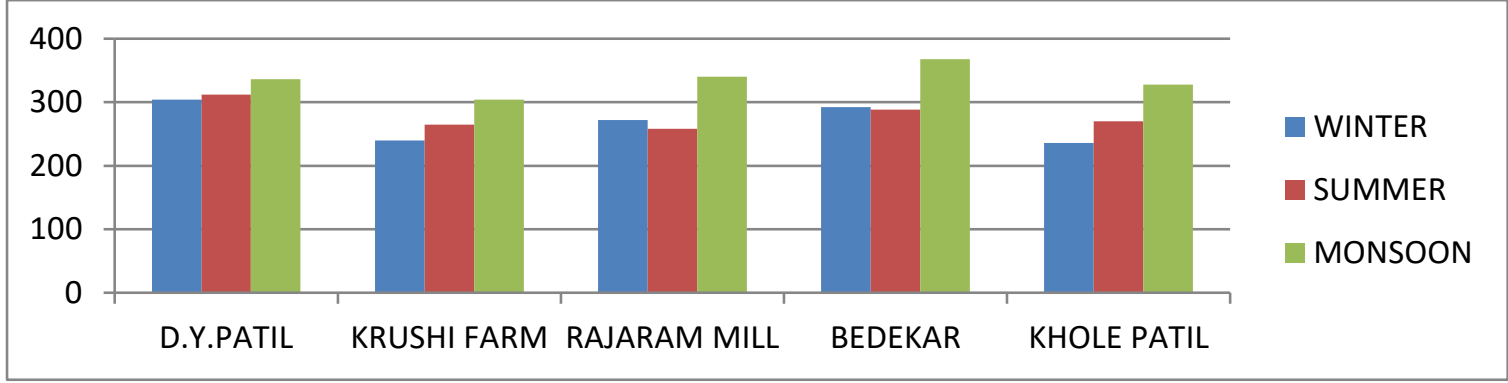

Fig 10 comparison of alkalinity of bore well water sample

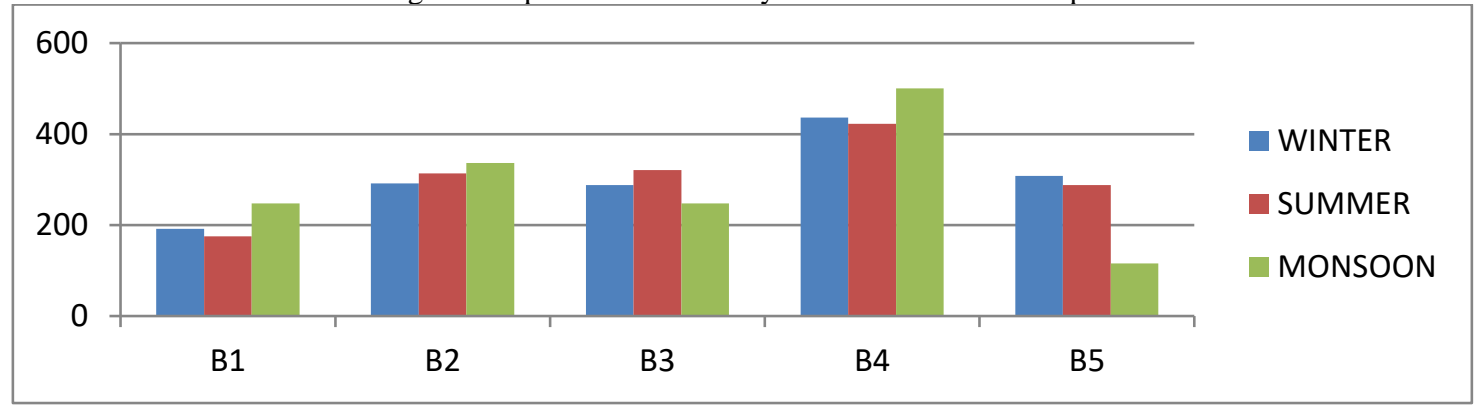

Fig 11 comparison of TDS of well water sample

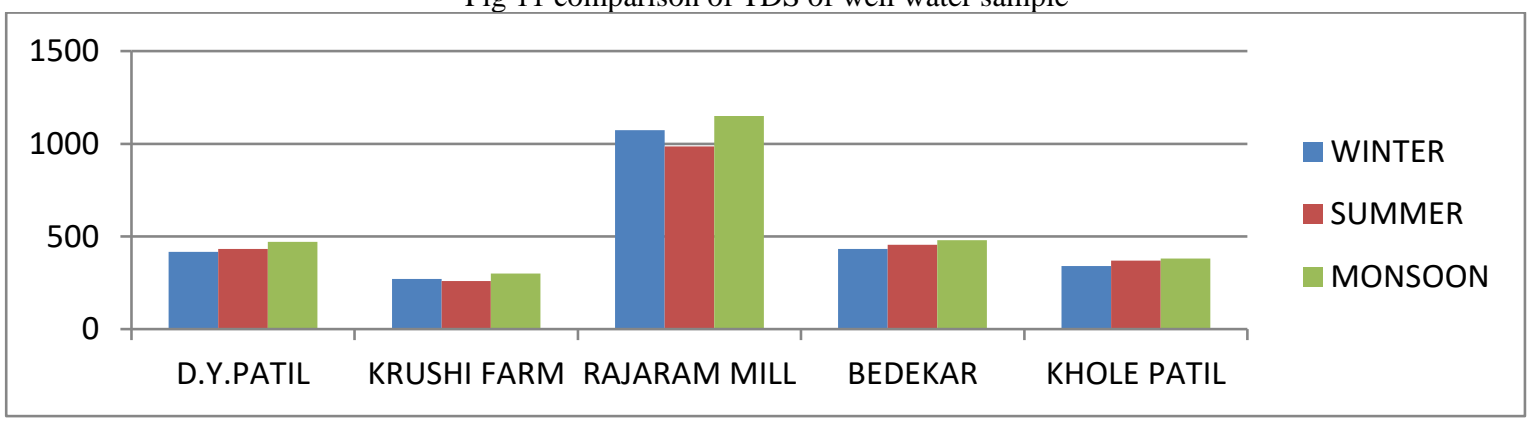


Fig 12 comparison of TDS of bore well water sample

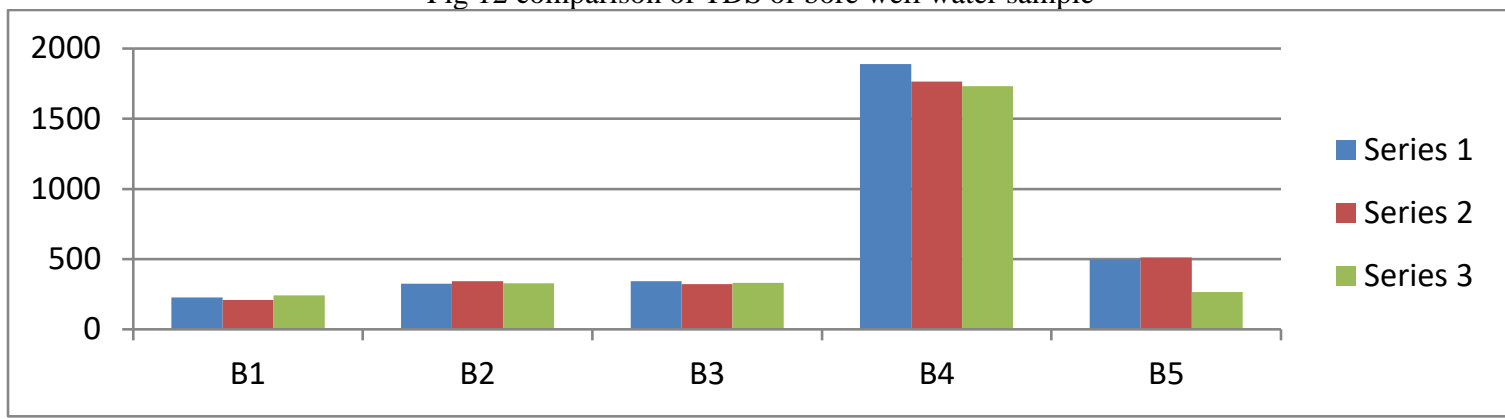

\section{RESULTS}

The results give an insight into the ground water quality of collected samples. All the samples were colourless and odourless.

1 The $\mathrm{pH}$ value of well water was observed in the range of 7.15 to 8.9 at this site and $\mathrm{pH}$ value of bore well water was observed in the range of 6.8 to 8.12 at this site. The $\mathrm{pH}$ values were within the prescribed limit of 6.5-8.5 according to I.S 10500-2012.

2 The turbidity of well water samples was observed in the range of 0 to 12.5 and turbidity of bore well water samples was observed in the range of 0 to 8.2. The turbidity values were within the prescribed limit of 1-5 according to I.S 10500-2012.

3 The temperature of well water samples was observed in the range of $25^{\circ} \mathrm{C}$ to $29^{\circ} \mathrm{C}$ and temperature of bore well water samples was observed in the range of $22^{\circ} \mathrm{C}$ to $28^{\circ} \mathrm{C}$

4 Dissolved Oxygen ( D.O) of well water was observed in the range of 1.06 to $5.4 \mathrm{mg} / \mathrm{L}$. Dissolved Oxygen ( D.O) of bore well water was observed in the range of 1.6 to 4.8 $\mathrm{mg} / \mathrm{L}$ the values were below $5 \mathrm{mg} / \mathrm{L}$ for the nearest samples of the dumping site which clearly indicate the pollution due to increased content of decomposable organic matter. D.O is dependent on the physical, chemical and biological activities prevailing in the water body and varies with the water temperature and altitudes.

5 The total hardness of well water was observed in the range of 180 to $876 \mathrm{mg} / \mathrm{L}$. The total hardness of bore well water was observed in the range of 148 to $1400 \mathrm{mg} / \mathrm{L}$. The total hardness values were within the prescribed limit of 200-600 mg/L according to I.S 1983. The total hardness is generally attributed by the calcium and magnesium concentration.

6 The chloride concentration in well water samples were found to be in range 48 to $510 \mathrm{mg} / \mathrm{L}$. The chloride concentration in bore well water samples were found to be in range 38 to $1278 \mathrm{mg} / \mathrm{L}$ The concentration of chloride in the samples were attributed by the dissolution of chlorinated soluble salts present in solid waste leachate. The chloride values were within the prescribed limit of 250-1000 according to I.S 10500-2012.

7 The alkalinity of well water was observed in the range of 236 to $368 \mathrm{mg} / \mathrm{L}$. The alkalinity of bore well water was observed in the range of 116 to $500 \mathrm{mg} / \mathrm{L}$. The alkalinity values were within the prescribed limit of 200 to 600 according to I.S 10500-2012.

8 The calcium content of well water was ranged from 50 to $135 \mathrm{mg} / \mathrm{L}$. The calcium content of bore well was ranged from 52 to $160 \mathrm{mg} / \mathrm{L}$. The calcium values were within the prescribed limit of 75 to 200 according to I.S 10500-2012.

9 The nitrate content of well water was ranged from 7.22 to $50 \mathrm{mg} / \mathrm{L}$. The nitrate content of bore well water was ranged from 2.38 to $27.7 \mathrm{mg} / \mathrm{L}$. The nitrate values were within the prescribed limit of 45 according to I.S 10500-2012.

10 The sulphate content of well water was ranged from 188 to $910 \mathrm{mg} / \mathrm{L}$. The sulphate content of bore well water was ranged from 11.73 to $650 \mathrm{mg} / \mathrm{L}$. The sulphate values were within the prescribed limit of 200to 400 according to I.S 10500-2012.

11 The Total Solids (TS) and the Total Dissolved Solids (TDS) concentration decreased with the increase in distance of sample water sources from the dumping site. The Total Dissolved Solids (TDS) concentration of well water was observed in the range of 260 to $1149 \mathrm{mg} / \mathrm{L}$. The Total Dissolved Solids (TDS) concentration of bore well water was observed in the range of 208 to $1888 \mathrm{mg} / \mathrm{L}$. The (TDS) values were within the prescribed limit of 500 to 2000 according to I.S 10500-2012.

12 Total suspended solids (TSS) concentration of well water was ranged from 180 to $415 \mathrm{mg} / \mathrm{L}$. Total suspended solids (TSS) concentration of bore well water was ranged from 197 to $1112 \mathrm{mg} / \mathrm{L}$.

13 Total solids (TS) concentration of well water was ranged from 483 to $1564 \mathrm{mg} / \mathrm{L}$. Total solids (TS) concentration of bore well water was ranged from 410 to $2915 \mathrm{mg} / \mathrm{L}$

\section{CONCLUSION}

It is also observed from the analysis that the ground water sample from D.y.patil well, bedekar well, rajaram mill area well water is not reasonable for drinking purpose legitimately without appropriate treatment. biraje panand bore well and D.y.patil bore well contain high amount of hardness, TDS, sulphates, so this water is not fit for drinking purpose. It is also observed from the analysis that the ground water samples nearest the dumping site was beyond the permissible limit and is not suitable for drinking purpose.

\section{REFERNCES}

[1] A. Andreadakis, C.Noutsopoulos, E.Gavalaki [1]. researched on program regarding water quality management and protection plan for Lake Plastira, Global Nest :the Int.j.vol5,no2,pp 99105,2003

[2] ShwetaTyagi, Bhavtosh Sharma Prashant Singh, and Rajendra Dobhal, [2] study on "Water Quality Assessment in Terms of Water Quality Index." American Journal of Water Resources, 2013, Vol. 1, No. 3, 34-38 
[3] Tirkey Poonam, Bhattacharya Tanushree, Chakraborty Sukalyan[3] study on water quality indices International Journal of Advances in Chemistry (IJAC) Vol.1, No.1, November 2015

[4] A.N.Prasad, K. A. Mamun, F. R. Islam, H. Haqva [4] research on Smart Water Quality Monitoring system for Fiji, using IoT and remote sensing technology. DOI: 10.1109/APWCCSE.2015.7476234

[5] B. Menakadevi, N. Ammu abirami [5] they study on determination quality of water automatically using low cost and in-pipe sensors. International Journal of Computer Science and Mobile Computing, Vol.3 Issue.9, September- 2014, pg. 732-740

[6] K. A. Unnikrishna Menon ${ }^{1}$, Divya $\mathrm{P}^{2}$, Maneesha V. Ramesh ${ }^{3}$ [6] they present the system architecture for a Wireless sensor Network which aids in River Water Quality Monitoring OIEEE 20180
[7] S.P.Bhalme [7]study on the analysis of drinking water parameters in an Educational institute situated in Hingna MIDC area, Nagpur.ISSN: 2248-9622 www.ijera.com Vol. 2, Issue 3, May-Jun 2012, pp.3155-3158

[8] Andreea-MihaelaDunca [8] This study focuses on water resources management and shows the need to enforce the existing international bilateral agreements and to implement the Water Framework Directive of the European Union in order to improve the water quantity and quality received by a downstream country of a common watershed, like Timis -Bega hydrographical basin, shared by two countries (Romania and Serbia). Hindawi Journal of Chemistry Volume 2018, Article ID 9073763 ,

[9] V.T. Patil and P. R. Patil [9] study on physicochemical characteristics of groundwater and municipal water in Amalner town. 